\title{
Article \\ Effects of FGFR Tyrosine Kinase Inhibition in OLN-93 Oligodendrocytes
}

\author{
Ranjithkumar Rajendran ${ }^{1}$, Gregor Böttiger $\left.{ }^{1}{ }^{(}\right)$, Niklas Dentzien $\left.{ }^{1}{ }^{(}\right)$, Vinothkumar Rajendran ${ }^{1}$, Bischand Sharifi ${ }^{1}$, \\ Süleyman Ergün ${ }^{2}$, Christine Stadelmann ${ }^{3}$, Srikanth Karnati ${ }^{2}$ (1) and Martin Berghoff ${ }^{1, *}$ \\ 1 Experimental Neurology, Department of Neurology, Justus Liebig University of Giessen, \\ 35385 Giessen, Germany; ranjithkumar.rajendran@neuro.med.uni-giessen.de (R.R.); \\ gregor.w.boettiger@med.uni-giessen.de (G.B.); niklas.dentzien@med.uni-giessen.de (N.D.); \\ vinothkumar.rajendran@neuro.med.uni-giessen.de (V.R.); bischand.sharifi@med.uni-giessen.de (B.S.) \\ 2 Institute of Anatomy and Cell Biology, University of Würzburg, \\ Koellikerstrasse 6, 97080 Würzburg, Germany; sueleyman.erguen@uni-wuerzburg.de (S.E.); \\ srikanth.karnati@uni-wuerzburg.de (S.K.) \\ 3 Institute for Neuropathology, Clinic for Neurology, University Medical Center, 37075 Göttingen, Germany; \\ cstadelmann@med.uni-goettingen.de \\ * Correspondence: martin.berghoff@neuro.med.uni-giessen.de; Tel.: +49-641-98544306; Fax: +49-641-98545329
}

Citation: Rajendran, R.; Böttiger, G.; Dentzien, N.; Rajendran, V.; Sharifi,

B.; Ergün, S.; Stadelmann, C.; Karnati, S.; Berghoff, M. Effects of FGFR Tyrosine Kinase Inhibition in OLN-93 Oligodendrocytes. Cells 2021, 10, 1318. https://doi.org/10.3390/ cells10061318

Academic Editor: Antoni Wiedlocha

Received: 6 April 2021

Accepted: 22 May 2021

Published: 25 May 2021

Publisher's Note: MDPI stays neutral with regard to jurisdictional claims in published maps and institutional affiliations.

Copyright: (c) 2021 by the authors. Licensee MDPI, Basel, Switzerland. This article is an open access article distributed under the terms and conditions of the Creative Commons Attribution (CC BY) license (https:// creativecommons.org/licenses/by/ $4.0 /)$.
Abstract: Fibroblast growth factor (FGF) signaling is involved in the pathogenesis of multiple sclerosis (MS). Data from neuropathology studies suggest that FGF signaling contributes to the failure of remyelination in MS. In $\mathrm{MOG}_{35}-55$-induced EAE, oligodendrocyte-specific deletion of FGFR1 and FGFR2 resulted in a less severe disease course, reduced inflammation, myelin and axon degeneration and changed FGF/FGFR and BDNF/TrkB signaling. Since signaling cascades in oligodendrocytes could not be investigated in the EAE studies, we here aimed to characterize FGFR-dependent oligodendrocyte-specific signaling in vitro. FGFR inhibition was achieved by application of the multi-kinase-inhibitor dovitinib and the FGFR1/2/3-inhibitor AZD4547. Both substances are potent inhibitors of FGF signaling; they are effective in experimental tumor models and patients with malignancies. Effects of FGFR inhibition in oligodendrocytes were studied by immunofluorescence microscopy, protein and gene analyses. Application of the tyrosine kinase inhibitors reduced FGFR1, phosphorylated ERK and Akt expression, and it enhanced BDNF and TrkB expression. Furthermore, the myelin proteins CNPase and PLP were upregulated by FGFR inhibition. In summary, inhibition of FGFR signaling in oligodendrocytes can be achieved by application of tyrosine kinase inhibitors. Decreased phosphorylation of ERK and Akt is associated with an upregulation of BDNF/TrkB signaling, which may be responsible for the increased production of myelin proteins. Furthermore, these data suggest that application of FGFR inhibitors may have the potential to promote remyelination in the CNS.

Keywords: multiple sclerosis; oligodendrocytes; dovitinib; AZD4547; FGFR signaling; myelin

\section{Introduction}

Demyelination of the central nervous system (CNS) causes degeneration of axons [1] associated with permanent disability [2-4]. The physiological response to demyelination is robust and leads to effective remyelination [5]. However, remyelination often fails in inflammatory demyelinating diseases such as MS $[2,6,7]$. The pivotal impediment for remyelination in MS is most likely not the recruitment of oligodendrocyte progenitor cells (OPCs) to lesions, but OPCs' inability to differentiate into mature myelin-producing oligodendrocytes (OLs) [8,9]. Growth factors have been associated with the differentiation of oligodendrocytes in demyelinating pathologies. These include brain derived neurotrophic factor (BDNF), nerve growth factor (NGF), insulin-like growth factor (IGF), platelet derived growth factor (PDGF), ciliary neurotrophic factor (CNTF) and FGF [10,11]. Molecular 
analyses of brain tissue suggest that FGF/FGF receptor (FGFR) signaling pathways are relevant to the pathogenesis of MS. In lesion areas, FGF1 is expressed in oligodendrocytes, astrocytes, microglia/macrophages and infiltrating lymphocytes [12]. FGF2 is mainly found in microglia/macrophages [13], whereas FGF9 is expressed in oligodendrocytes and astrocytes [14]. Further, the corresponding FGFR1 is upregulated in an OPC subpopulation in lesions [13]. Moreover, in the cerebrospinal fluid (CSF), FGF2 levels were increased in patients with MS, and their highest expression was found in relapse [15].

$M_{35}$-55-induced experimental autoimmune encephalomyelitis (EAE) is the most widely used animal model of MS. We recently investigated the role of oligodendrocytespecific deletion of FGFR1 and FGFR2 in EAE [16,17]. Cell-specific deletion of these genes decreased disease severity, reduced lymphocyte and macrophage/microglia infiltration, and resulted in less myelin and axon degeneration. Furthermore, changes in FGF/FGFR downstream signaling and the BDNF/TrkB pathway were induced by oligodendrocytespecific FGFR deletions. Based on these findings of oligodendrocyte FGFR function on inflammation and neurodegeneration, we sought to characterize the mechanisms responsible for demyelination in particular with respect to myelin expression in oligodendroglia.

We hypothesized that in vitro application of FGFR inhibitors results in reduced proliferation, enhanced differentiation and upregulation of myelin associated proteins in OLs. To test our hypothesis, we used OLN-93 cells and treated them with AZD4547 and dovitinib. AZD4547 is a novel FGFR1-3 inhibitor with high oral bioavailability, selectivity and potency [18] down-regulating RAS-MAPK-ERK and phosphoinositide 3-kinase (PI3K)-Akt pathways [19], which was employed in Phase II studies for treatment of different cancers. The favorable side effect profile of AZD4547 makes it an auspicious candidate for inhibition of FGFR1-3 in humans [20,21]. Dovitinib is a multi-kinase inhibitor targeting FGFR1-3 along with vascular endothelial growth factor (VEGF), platelet-derived growth factor receptor (PDGFR) and tyrosine kinases of Class III (KIT, RET) [22]. It is a well-known tyrosine kinase inhibitor that has been trialed in clinical studies for its effect on various cancers. Other than AZD4547, dovitinib targets a broader spectrum of receptors, and may therefore, provide insights on the role of complementary growth factor receptors. Overall, receptor-targeted modulation of FGFR signaling has yielded promising results in cancer disease models $[23,24]$ and potent inhibitors of FGFRs are currently tested in cancer treatment trials [25].

Administration of these FGFR tyrosine kinase inhibitors resulted in less FGFR1 expression and less phosphorylation of Akt and ERK. Interestingly, AZD4547 and dovitinib both promoted the upregulation of TrkB/BDNF and enhanced expression of myelin proteins. Thus, this study revealed that AZD4547 and dovitinib are efficacious in inducing differentiation of OLN-93 oligodendrocytes and the promotion of myelination in vitro. The findings presented here support the view of FGFR inhibition as a therapeutic tool to enable remyelination in MS.

\section{Materials and Methods}

\subsection{Cell Culture}

The permanent oligodendroglia cell line OLN-93 was kindly provided by Prof. Markus Kipp, University of Rostock, Germany. Cells were cultured in growth medium consisting of Dulbecco's Modified Eagle Medium (DMEM) (Gibco, Invitrogen, Carlsbad, CA, USA) supplemented with $10 \%$ heat inactivated FBS (Gibco, Invitrogen, Carlsbad, CA, USA) and $1 \%$ penicillin/streptomycin (Life Technologies Limited, Renfrew, UK). Cells were maintained at $37{ }^{\circ} \mathrm{C}$ in an incubator (Sanyo, Osaka, Japan) at a controlled atmosphere (95\% humidity, $5 \% \mathrm{CO}_{2}$ ). At a confluence of at least $80 \%$, cells were sub-cultured. Washing with PBS (PAN Biotech, Aidenbach, Germany) was followed by cell detachment using $0.5 \%$ Trypsin-EDTA (Gibco, Invitrogen, Carlsbad, CA, USA), centrifugation of detached cells and resuspension in fresh medium. Experiments were performed at passage 8-20. 


\subsection{Experimental Treatment of Cells}

Four groups were deployed and treated with either dovitinib (Selleck Chemicals, Houston, TX, USA), AZD4547 (Selleck Chemicals, Houston, TX, USA), FGF2 (R\&D Systems, Minneapolis, MN, USA) or utilized without treatment as a control. AZD4547 and dovitinib were dissolved in dimethyl sulfoxide (DMSO) (Carl Roth GmbH, Karlsruhe, Germany) and stored at $-20^{\circ} \mathrm{C}$ until use. Compounds were applied at a concentration of $1 \mu \mathrm{M}$ (AZD4547, dovitinib) or $25 \mathrm{ng} / \mathrm{mL}$ (FGF2). DMSO controls have been included in all experiments. The inhibitors were applied at an effective concentration as previously established [18,26]. All treatments were added to DMEM growth medium and setups were incubated for $24 \mathrm{~h}$, after which appropriate amounts of cells were taken for further analysis.

\subsection{Proliferation Measurement}

To assess cell proliferation under different treatment conditions several assays were utilized. Cells were grown in DMEM culture medium supplemented with 10\% FBS and the respective compounds at humidified conditions. After $24 \mathrm{~h}$ of incubation manual counting was performed using a Neubauer improved chamber (Karl Hecht "Assistant", Altnau, TG, Switzerland) and Trypan blue dye (Carl Roth, Karlsruhe, Germany) as described by others [27]. For photometric evaluation of proliferation, cells were seeded at $2 \times 10^{4}$ cells/well in a 96 well plate (Greiner Bio-One, Frickenhausen, Germany) before treatment. After $24 \mathrm{~h}$ of treatment, a WST-1 assay (Roche Applied Science, Mannheim, Germany) was carried out as described by manufacturer. Absorption was measured by ELISA-Reader (Multiscan EX, Thermo Fisher Scientific, Langenselbold, Germany) at a wavelength of $405 \mathrm{~nm}$ using a reference wavelength of $492 \mathrm{~nm}$.

\subsection{Cytotoxicity Assessment}

Possible cytotoxic effects of applied compounds were studied by measuring lactate dehydrogenase (LDH) in the supernatant of incubated cells (96 well plate, $0.5 \times 10^{4}$ cells/well) using a prefabricated kit (Cytotoxicity Detection Kit (LDH), Roche Diagnostics, Mannheim, Germany). Cell plates were centrifuged for $10 \mathrm{~min}$ at $250 \times \mathrm{g}$ and supernatant was used to measure absorbance at $492 \mathrm{~nm}$ (reference wavelength: $620 \mathrm{~nm}$ ) to calculate cytotoxicity as described by manufacturer.

\subsection{Western Blotting and Antibodies}

For protein extraction, cells were incubated in T-75 flasks for $24 \mathrm{~h}$ as described above. Media was then removed, and cells were washed with PBS. After centrifugation, buffer was removed, cells were lysed and protein concentration was quantified in a nanophotometer (Implen $\mathrm{GmbH}$, Munich, Germany) according to the manufacturer's instructions. After normalization, proteins were separated by 10\% SDS-PAGE gel electrophoresis. Separated protein was transblotted to a nitrocellulose membrane (GE Healthcare, Amersham ${ }^{\mathrm{TM}}$ Protran $^{\mathrm{TM}}$, Buckinghamshire, UK) and after blocking with 5\% BSA (Merck, Darmstadt, Germany) primary antibodies were applied in an appropriate dilution in tris buffered saline with tween 20 (TBST) with 5\% BSA and incubated overnight. The antibodies used in this study can be found in Supplementary (Supplementary Table S1). SuperSignal ${ }^{\mathrm{TM}}$ West Pico chemiluminescent substrate (Thermo Fisher Scientific, Waltham, MA, USA) was used to visualize the protein bands imaged in an ECL Chemocam Imager (Intas-Science, Göttingen, Germany) and quantified using ImageJ software (NIH, Stapleton, NY, USA).

\subsection{RNA Analysis}

For RNA extraction, cells were incubated in T-75 flasks for $24 \mathrm{~h}$ as described above. Media was then removed, and cells were washed with PBS. After centrifugation, buffer was removed and the cellular RNA extracted with peqGOLD Total RNA Kit as described by the manufacturer (VWR, PEQLAB, Darmstadt, Germany). Total amount of RNA was quantified in a nanophotometer and $1 \mu \mathrm{g}$ of RNA was used for subsequent cDNA synthesis with QuantiTect Reverse Transcription Kit (Thermo Fisher Scientific, QIAGEN, Hilden, 
Germany). All samples were diluted in $200 \mu \mathrm{L}$ RNAse free $\mathrm{H}_{2} \mathrm{O}$ from which $1 \mu \mathrm{L}$ was used for comparative quantitative real time PCR (qRT-PCR) MicroAmp ${ }^{\circledR}$ Fast Reaction Tubes (Applied Biosystems, Darmstadt, Germany). A total $7 \mu \mathrm{L}$ of $\mathrm{H}_{2} \mathrm{O}, 1 \mu \mathrm{L}$ of forward and reverse primer (FP and $\mathrm{RP}$, respectively) and $10 \mu \mathrm{L}$ of $\mathrm{SYBR}^{\circledR}{ }^{\circledR}$ Green $\mathrm{qPCR}$ Supermix (Bio-Rad, Hercules, CA, USA) was added. Primers for FGFR1, BDNF, TrkB, PLP, CNPase, $S E M A 3 A, T G F \beta$ and GAPDH as internal control were purchased from Eurofins Genomics (Ebersberg, Germany). The primers used in this study can be found in Supplementary Table S2. PCR was performed in StepOne ${ }^{\circledR 囚}$ Real-Time PCR system (Applied Biosystems, Darmstadt, Germany) using StepOne ${ }^{\mathrm{TM}}$ Software v2.3 (Applied Biosystems, Darmstadt, Germany) in 40 repetitive cycles: Denaturation at $95^{\circ} \mathrm{C}$ for $15 \mathrm{~s}$ followed by annealing at $60{ }^{\circ} \mathrm{C}$ for $1 \mathrm{~min}$. The three biological replicates performed contained negative controls without template cDNA and were executed in technical duplicates. Quantification of the results was carried out using the $2^{-\Delta \Delta C t}$ method [28].

\subsection{Immunofluorescence}

To address the morphological alterations induced by FGFR inhibition, immunofluorescence was performed. OLN-93 cells were seeded on sterilized coverslips (R. Langenbrinck, Emmendingen, Germany) in 24-well-plates (GreinerBioOne, Frickenhausen, Germany) at a final density of $6 \times 10^{4}$ cells/well and treated according to their assigned group as described in section experimental treatment of cells. Cells were washed with PBS, fixed using 4\% paraformaldehyde and incubated in PBS containing 0.5\% Triton X-100 (SigmaAldrich, Steinheim, Germany) for permeabilization. After blocking in PBS with 5\% BSA, cells were incubated overnight at $4{ }^{\circ} \mathrm{C}$ with primary antibodies, washed and stained with respective fluorescent secondary antibodies (as listed in Supplementary Table S1). Negative controls omitting the secondary antibody were included for each treatment. Cells were counter-stained with DAPI (Carl Roth, Karlsruhe, Germany) and subsequently mounted onto microscope slides using Fluorescence Mounting Medium (DAKO, Agilent, CA, USA). Images were taken with Axioplan 2 Fluorescence Microscope (Carl Zeiss, Jena, Germany) at a magnification of $50 \times$ and $400 \times$ using ZEN software for microscope (Zen 2.3, ZEISS, Jena, Germany) for image acquisition and processing. For counting of positive cells, 10 areas on every slide were randomly selected and a total of 30 cells was counted in each spot at $50 \times$ magnification regarding the intensity and location of signal. The total number of cells was determined by the DAPI counterstain.

\subsection{Statistical Analysis}

All experiments were conducted at least in 3-6 replicates. Data were analyzed using Sigmaplot 14 (Systat, San Jose, CA, USA). Depending on distribution of data, differences between groups were analyzed either by using ANOVA or Kruskal-Wallis ANOVA followed by a Tukey post hoc test or by Dunn's Method. $p<0.05$ was considered statistically significant $\left({ }^{*} /{ }^{\#} \hat{=} p<0.05,{ }^{* *} /{ }^{\# \#} \hat{=} p<0.005,{ }^{* * *} /{ }^{\# \# \#} \hat{=} p<0.001\right)$. Values are shown as mean \pm standard error of the mean (SEM).

\section{Results}

\subsection{FGFR Inhibition Reduces Proliferation of OLN-93 Cells}

To study whether AZD4547 and dovitinib alter proliferation, OLN-93 cells were treated with these inhibitors. AZD4547 and dovitinib resulted in less proliferation of OLN-93 cells compared to untreated cells (dovitinib vs. control: $p=0.002$; AZD4547 vs. control: $p=0.012$; dovitinib vs. FGF2: $p<0.001$; AZD4547 vs. FGF2: $p<0.012$ ) (Figure 1A). In contrast, application of FGF2 did not affect proliferation of OLN-93 cells (Figure 1A). 

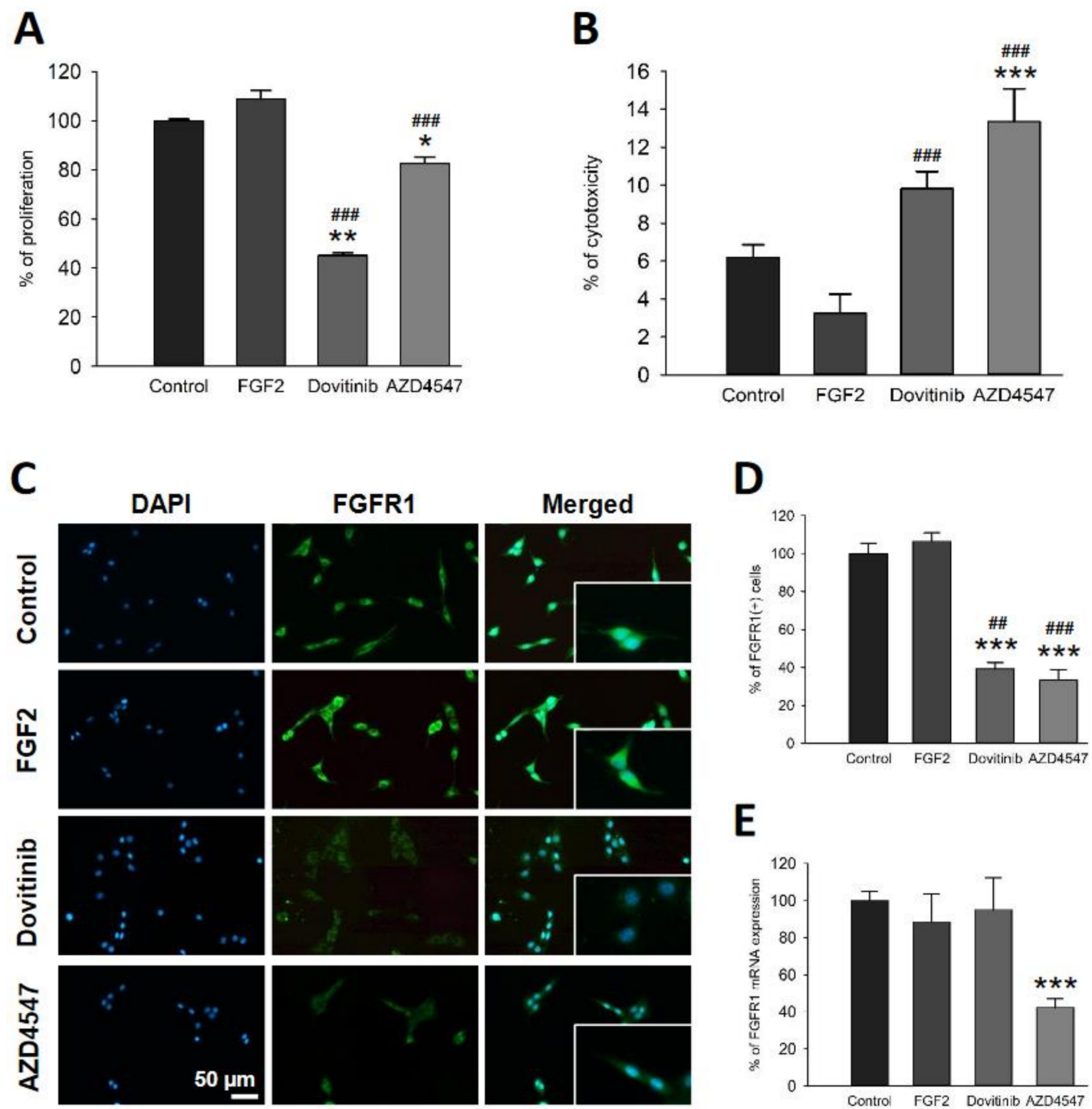

\section{E}

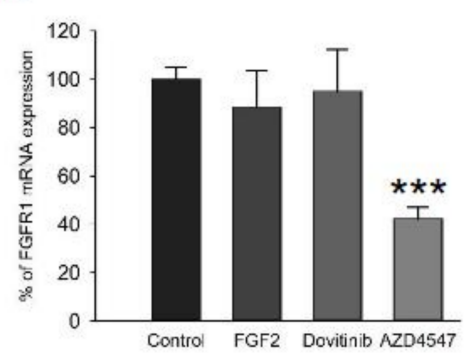

Figure 1. Cell viability (A,B) and FGFR expression (C-E) of OLN-93 cells incubated with dovitinib, AZD4547 or FGF2 for $24 \mathrm{~h}$. Both FGFR inhibitors induced anti-proliferative responses in OLN-93 cells (A), while only AZD4547 was cytotoxic to these cells (B). Representative sections of immunofluorescence staining (C). Quantitative analysis of immunofluorescence staining revealed reduced numbers of FGFR ${ }^{+}$cells after dovitinib and AZD4547 treatment (D). FGF2 did not affect the number FGFR1 ${ }^{+}$cells. qRT-PCR showed downregulation of FGFR (FGFR1) mRNA only in cells treated with AZD4547 (E). Data are presented as mean \pm SEM. ${ }^{*} p<0.05,{ }^{* *} p<0.005,{ }^{* * *} p<0.001$ vs. control; ${ }^{\# \#} p<0.005,{ }^{\# \# \#} p<0.001$ vs. FGF2.

\subsection{Inhibition of FGFR Is Cytotoxic to OLN-93 Cells}

As these compounds inhibit growth factor receptors involved in cell survival, we investigated possible cytotoxic effects on OLN-93 cells by means of a LDH assay. Both substances were deployed at a concentration of $1 \mu \mathrm{M}$ throughout the experiment. LDH levels in the supernatant of the treated cells revealed a significant cytotoxic effect of AZD4547 $(p<0.001)$, while dovitinib did not exert cytotoxicity in comparison to control (Figure 1B).

\subsection{FGFR1 Expression Is Reduced by FGFR Inhibition}

In the present study we investigated specific effects of pharmacological FGFR inhibition in oligodendrocytes by immunostaining and comparative qRT-PCR, after previously characterizing the effects of genetic FGFR silencing in OLs in the EAE model [16,17]. Application of AZD4547 and dovitinib resulted in a significant reduction of FGFR1 ${ }^{+}$cells 
compared to control $(p<0.001)$ (Figure 1C,D). FGF2 did not affect FGFR1 expression on cellular or mRNA levels (Figure $1 \mathrm{C}-\mathrm{E}$ ). While dovitinib treatment decreased the overall number of FGFR1 ${ }^{+}$cells, it did not affect FGFR1 mRNA expression. Cells treated with AZD4547 expressed less FGFR1 mRNA ( $p=0.009)$ (Figure 1E).

\subsection{FGFR Inhibition Decreased Phosphorylation of FGFR Downstream Signaling via Akt and ERK}

After studying the proliferative and cytotoxic effects of AZD4547 and dovitinib, we investigated whether these substances might be involved in FGFR signaling. For this purpose, we conducted Western blot and immunofluorescence staining for pERK and pAkt to examine the relative activation of these pathways following FGFR inhibition. The number of pAkt ${ }^{+}$cells was significantly reduced by AZD4547 and dovitinib $(p<0.001)$ (Figure 2A,B). We observed a trend towards lower abundance for dovitinib compared to control $(p=0.131)$ (Figure 2C,D). Fewer $\mathrm{pERK} \mathrm{K}^{+}$cells were detectable by immunofluorescence after treatment with AZD4547 or dovitinib $(p<0.001)$ (Figure 3A,B). pERK protein levels were unchanged (Figure 3C,D).

A
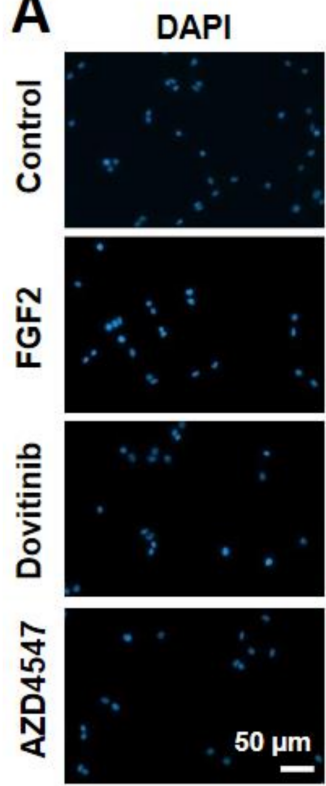

C
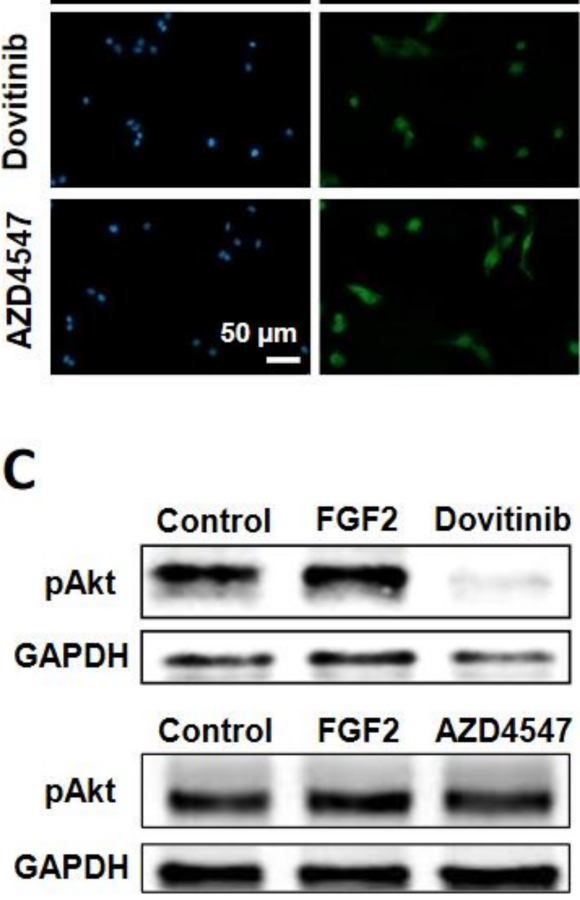

B
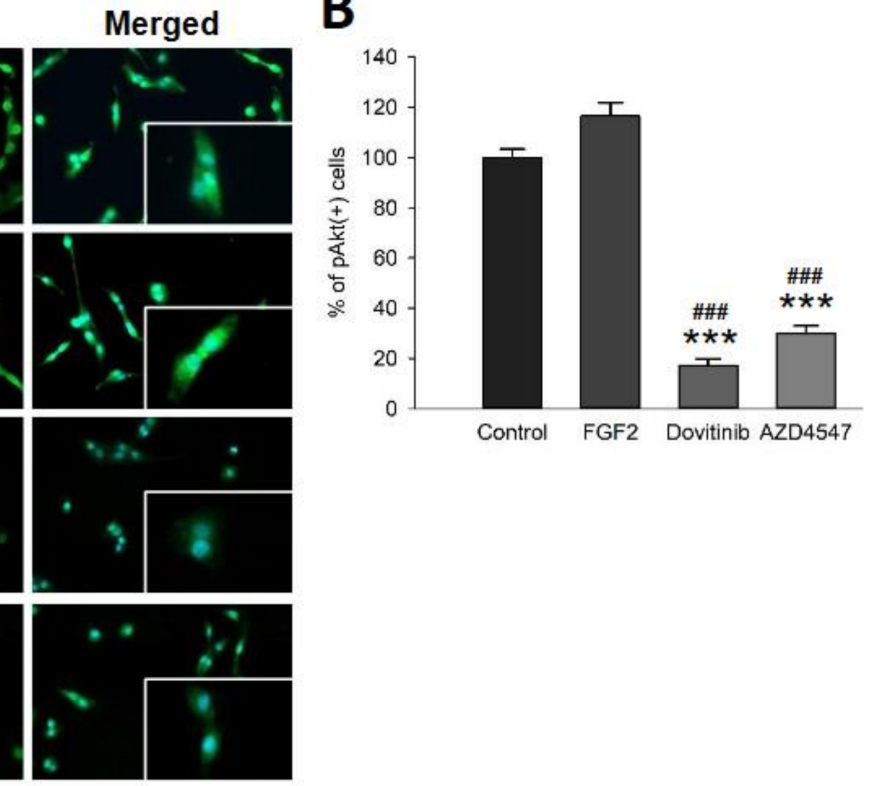

D

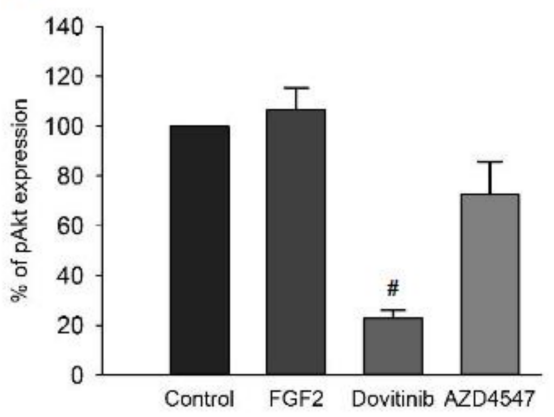

Figure 2. Cellular distribution (A,B) and protein expression (C,D) of pAkt. Representative sections of immunofluorescence staining (A). Quantification of fluorescence exposed a reduction in pAkt ${ }^{+}$cell count for both inhibitors to less than $60 \%$ (B). Representative Western blot images of pAkt analysis (C). pAkt levels as quantified by Western blot (D). Data are presented as mean \pm SEM. ${ }^{* * *} p<0.001$ vs. control; ${ }^{\#} p<0.05,{ }^{\# \# \#} p<0.001$ vs. FGF2. 

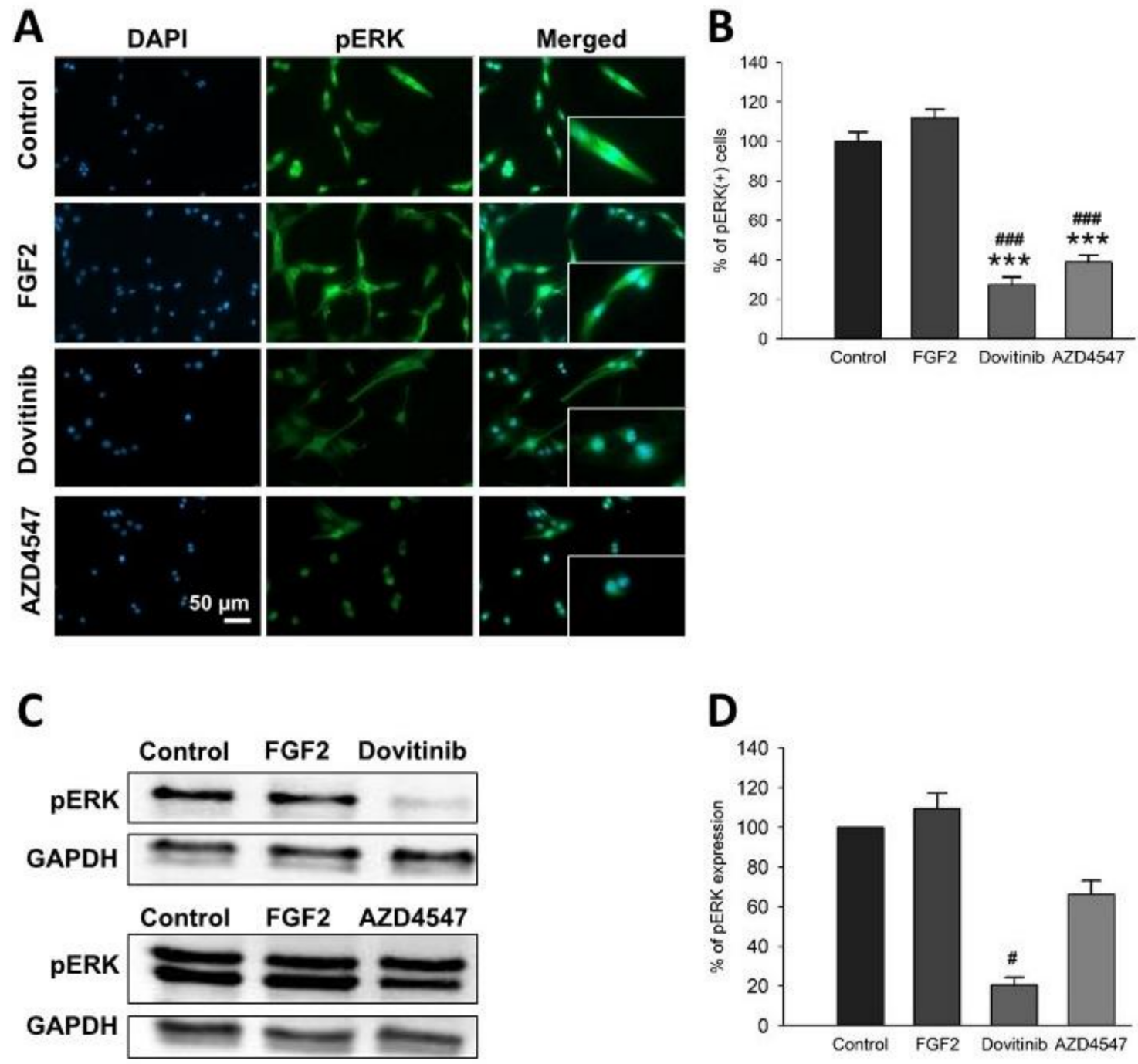

Figure 3. Cellular staining (A,B) for pERK and its protein expression (C,D). Representative sections for distribution and prevalence of $\mathrm{pERK}(\mathrm{A})$. The number of $\mathrm{pERK}^{+}$cells was reduced by more than $40 \%$ in all groups treated with FGFR inhibitors (B). Representative images of pERK Western blot (C). pERK protein levels were reduced by dovitinib (D). Data are presented as mean \pm SEM. ${ }^{* * *} p<0.001$ vs. control; ${ }^{\#} p<0.05,{ }^{\# \#} p<0.001$ vs. FGF2.

\subsection{The Expression of Neuroprotective BDNF and Its Receptor TrkB Is Elevated Following Inhibition of FGFR Signaling}

We next studied the neurotrophin BDNF and its receptor TrkB, which are known to play an important role in myelination $[29,30]$. Application of dovitinib resulted in an increase in the number of $\mathrm{BDNF}^{+}$cells $(p=0.005)$ (Figure $\left.4 \mathrm{~A}, \mathrm{~B}\right)$ and TrkB ${ }^{+}$cells $(p<0.001)$ (Figure 5A,B). Treatment with AZD4547, however, increased only the number of TrkB ${ }^{+}$ $(p=0.002)$ (Figure $5 \mathrm{~A}, \mathrm{~B})$ but not $\mathrm{BDNF}^{+}$cells (Figure $\left.4 \mathrm{~A}, \mathrm{~B}\right)$. Dovitinib caused an upregulation of BDNF and TrkB proteins $(p<0.001)$ (Figure $4 \mathrm{D}, \mathrm{E}$ and Figure 5D,E). AZD4547 did not affect protein levels of TrkB or BDNF (Figure 4D,E and Figure 5D,E). In contrast to these findings, mRNA encoding for BDNF $(p<0.001)$ was increased by AZD4547 (Figure 4C). Furthermore, NTRK2 mRNA expression was elevated after AZD4547 treatment $(p<0.001)$. Treatment with dovitinib did not alter mRNA levels of BDNF or NTRK2. 

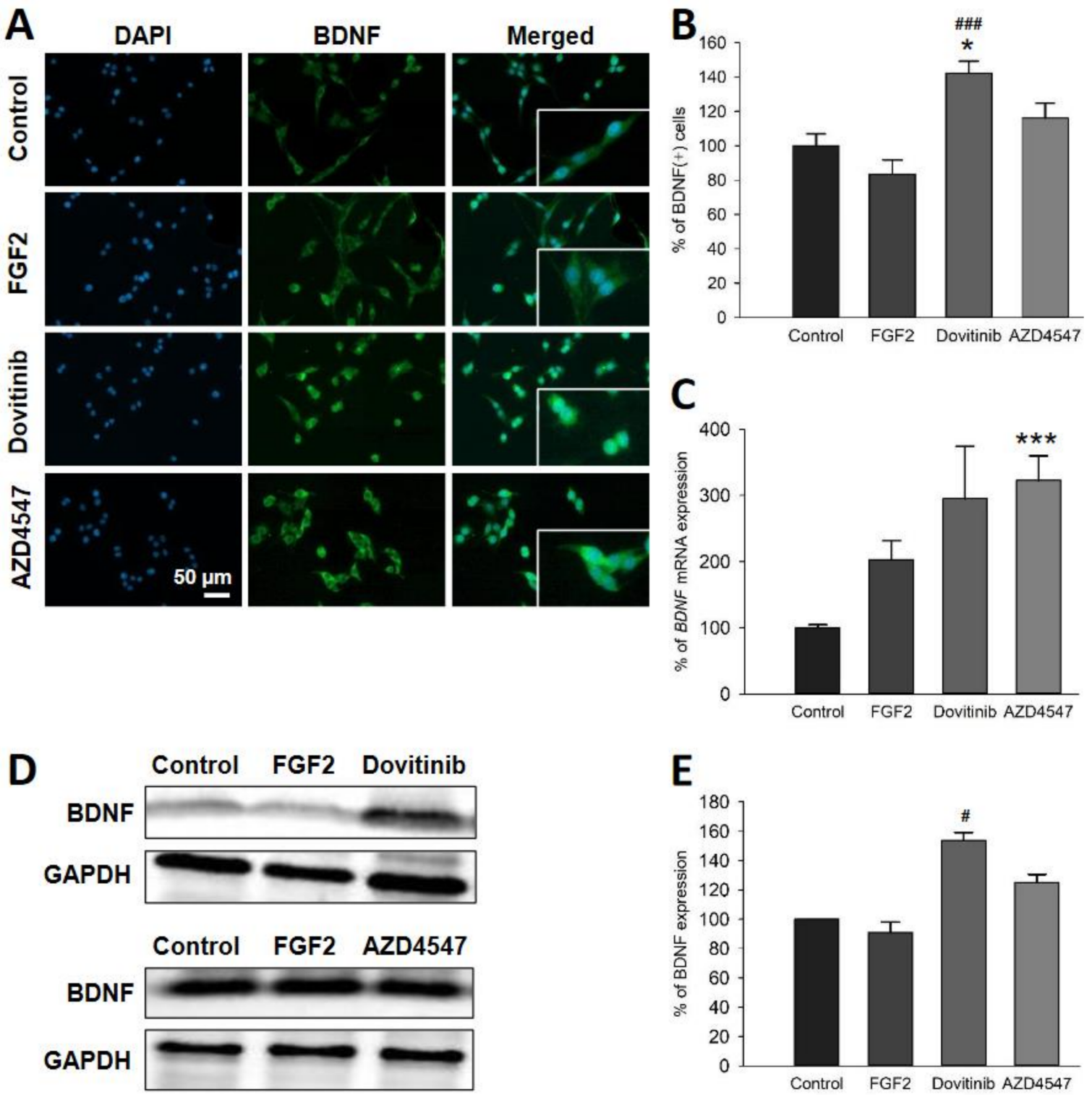

Figure 4. Cellular distribution (A,B), mRNA expression (C) and total amount of BDNF protein (D,E). Representative images are shown for immunofluorescence staining (A). Quantification of fluorescence showed a $40 \%$ enhancement of BDNF ${ }^{+}$cell numbers by dovitinib (B). BDNF (BDNF) mRNA was abundant after inhibition with AZD4547 (C). Representative Western blot bands of BDNF protein expression (D). BDNF protein expression was increased by dovitinib (E). Data are presented as mean \pm SEM. ${ }^{*} p<0.05,{ }^{* * *} p<0.001$ vs. control; ${ }^{\#} p<0.05,{ }^{\# \# \#} p<0.001$ vs. FGF2.

\subsection{Expression of PLP and CNPase in OLN-93 Cells Is Increased by FGFR Inhibition}

To assess whether pharmacological inhibition of FGFR induces myelination, we investigated the expression of key myelin protein components [31]. Indeed, immunofluorescence staining showed a significant increase in $\mathrm{PLP}^{+}$and $2^{\prime}, 3^{\prime}$-Cyclic-nucleotide $3^{\prime}-$ phosphodiesterase (CNPase) $)^{+}$cells to both compounds $(p<0.001)$ (Figures $6 \mathrm{~A}, \mathrm{~B}$ and $7 \mathrm{~A}, \mathrm{~B}$ ) Further, Western blot analysis of dovitinib treated OLN-93 cells showed abundance for PLP compared to FGF2 $(p=0.026)$. In contrast, AZD4547 treated OLN-93 cells did not show changes in PLP protein levels (Figure 6D,E). PLP1 mRNA was elevated by both inhibitors (AZD4547: $p=0.006$; dovitinib: $p=0.005)$ compared to control and FGF2 $(p<0.001)$ (Figure 6C). In addition, CNPase protein levels were also increased by both inhibitors versus FGF2 (AZD4547: $p=0.03$; dovitinib: $p=0.018$ ) (Figure 7D,E). Similarly, comparative qRT-PCR showed increased mRNA levels of CNP for AZD4547 and dovitinib (AZD4547: 
$p<0.001$; dovitinib: $p=0.002)$, and FGF2 $(p<0.001)$. Conversely, FGF2 treatment of oligodendrocytes significantly reduced mRNA levels of both PLP $(p=0.043)$ and CNP $(p<0.001)$ (Figures 6C and 7C).
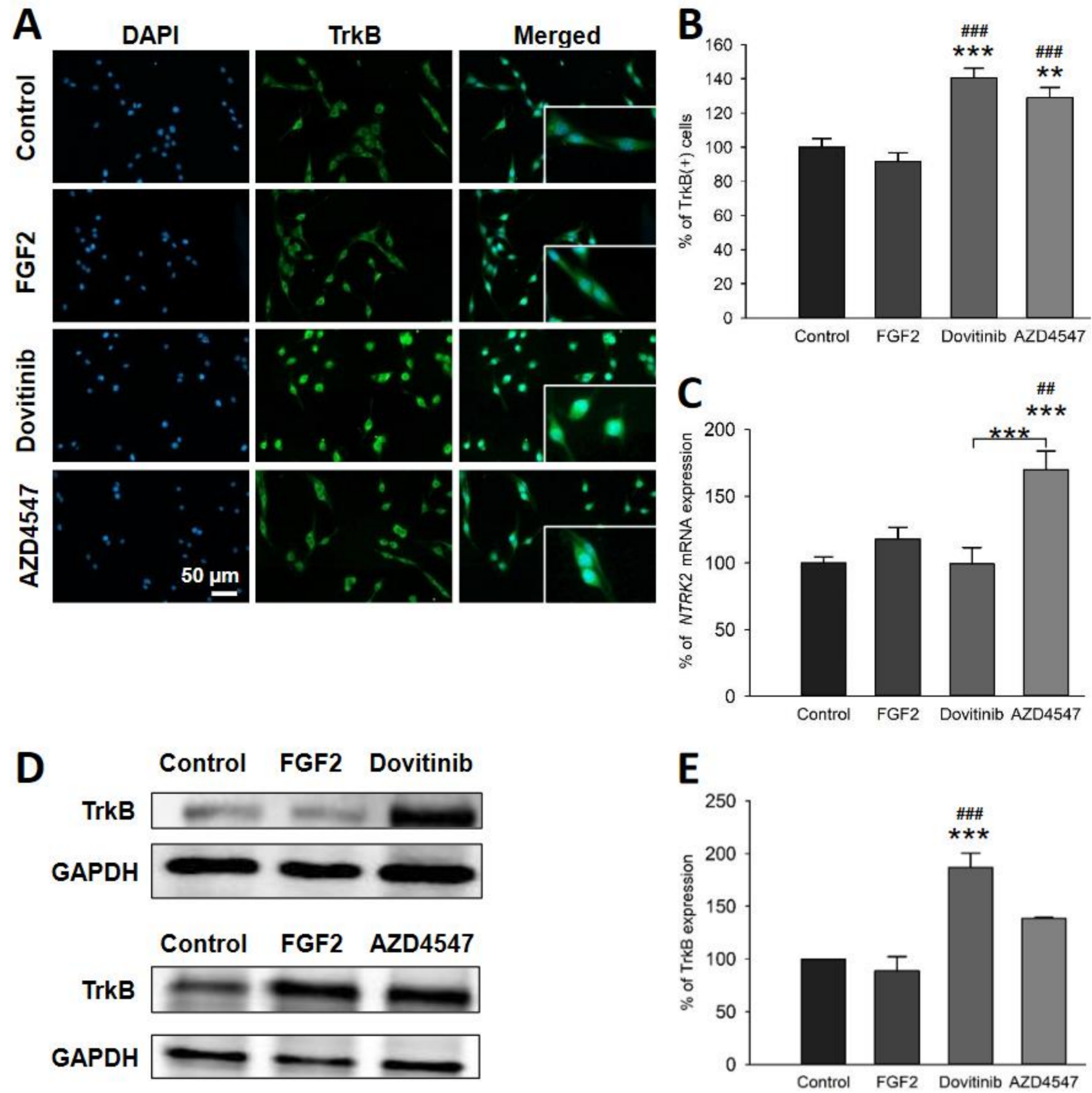

Figure 5. Number of $\operatorname{TrkB}^{+}$cells (A,B), TrkB mRNA (C) and protein levels (D,E). Representative sections of immunofluorescence staining (A). Analysis of immunofluorescence staining revealed increased numbers of TrkB ${ }^{+}$cells by dovitinib and AZD4547 of more than 20\% (B). qRT-PCR showed an upregulation of TrkB (NTRK2) mRNA only in cells treated with AZD4547 (C). Representative Western blot images for TrkB (D). TrkB protein levels were increased by dovitinib (E). Data are presented as mean \pm SEM. ${ }^{* *} p<0.005,{ }^{* * *} p<0.001$ vs. control; ${ }^{* \#} p<0.005,{ }^{\# \#} p<0.001$ vs. FGF2. 

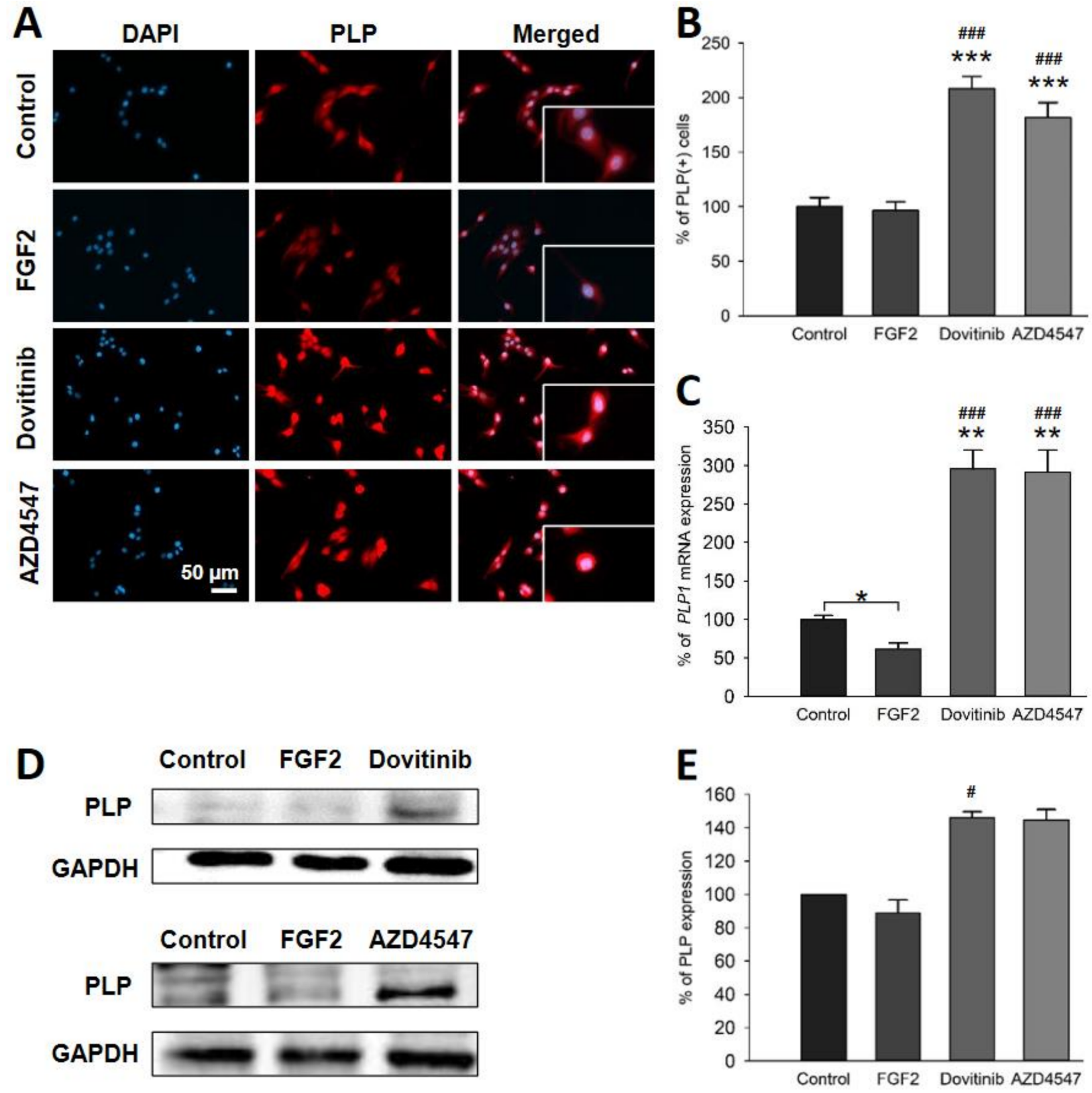

Figure 6. Distribution of $\mathrm{PLP}^{+}$cells (A,B), PLP mRNA expression (C) and its amount of total protein (D,E). Representative images for immunofluorescence staining (A). Quantification of fluorescence revealed doubled $\mathrm{PLP}^{+}$cell numbers after treatment with the FGFR inhibitors (B). mRNA expression of PLP (PLP1) was increased by treatment (C). Representative Western blot images of PLP analysis (D). PLP protein was increased by dovitinib (E). Data are presented as mean \pm SEM. ${ }^{*} p<0.05,{ }^{* * *} p<0.001$ vs. control; ${ }^{*} p<0.05,{ }^{\# \#} p<0.001$ vs. FGF2. 

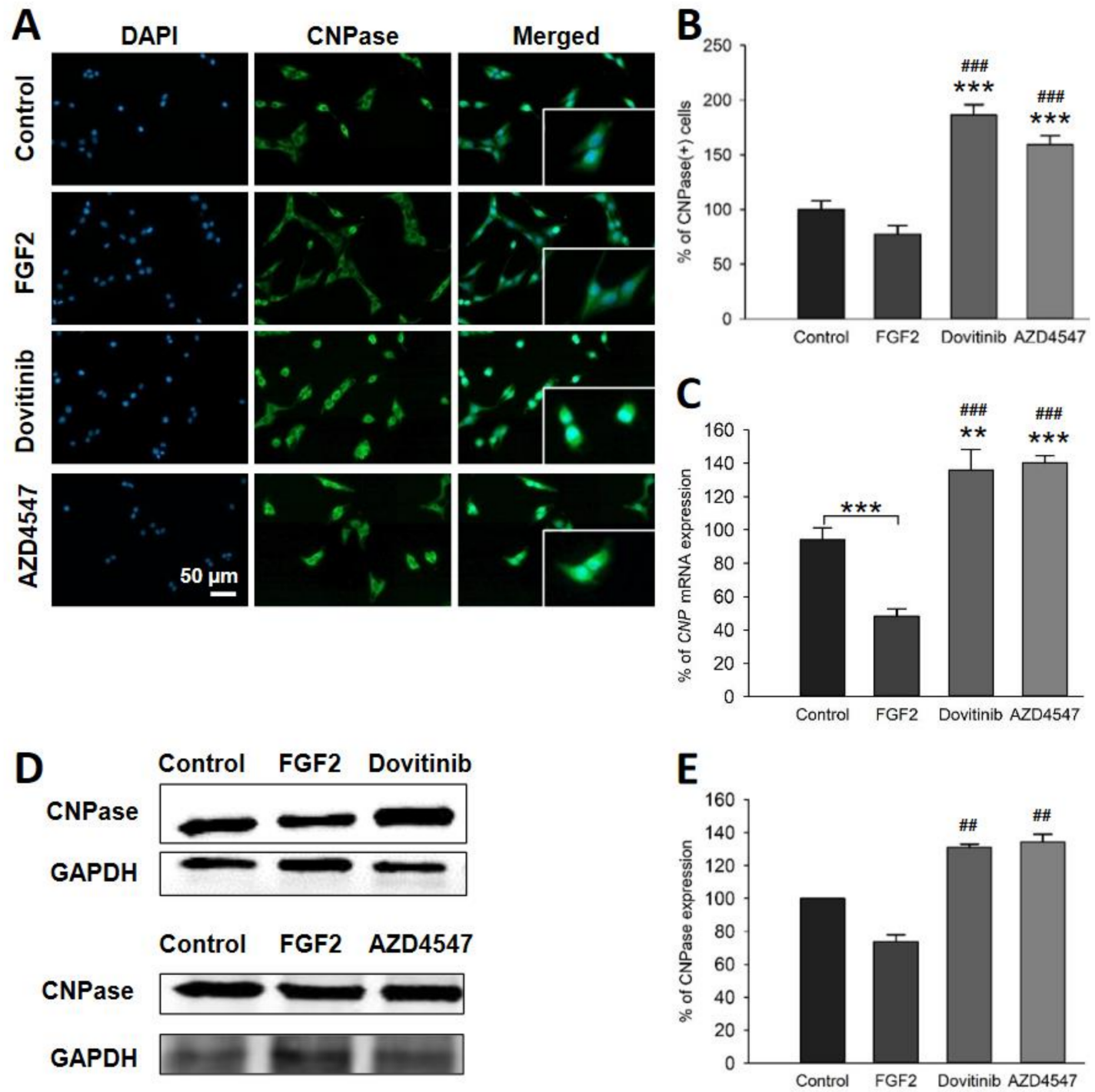

Figure 7. Immunofluorescence staining for $\mathrm{CNPase}^{+}$cells (A,B), CNPase mRNA (C) and protein levels (D). Depicted representative sections showed increase in distribution and prevalence of CNPase (A). The number of CNPase ${ }^{+}$cells was increased by more than $60 \%$ by AZD4547 or dovitinib treatment (B). mRNA analysis revealed decreased expression of CNPase (CNP) mRNA by FGF2; FGFR inhibitors enhanced mRNA levels (C). Representative Western blot bands for CNPase (D). Quantification of CNPase protein revealed increased expression by the inhibitors (E). Data are presented as mean \pm SEM. ${ }^{* *} p<0.005,{ }^{* * *} p<0.001$ vs. control; ${ }^{\# \#} p<0.005,{ }^{\# \# \#} p<0.001$ vs. FGF2.

\subsection{Expression of the Myelin Inhibitory Genes SEMA3A and TGFß Is Reduced after FGFR} Inhibition by AZD4547

Semaphorin 3A (SEMA3A) is one of the factors known to suppress (re)myelination by impeding OPC migration [32]. Transforming growth factor $\beta$ (TGF $\beta$ ) has ambivalent roles in demyelination. We, therefore, assessed their expression after FGFR inhibition on mRNA levels using comparative qRT-PCR. The analysis revealed an abating effect of AZD4547 on mRNA levels of TGFB1 (vs. control: $p<0.024$ ) as well as SEMA3A (vs. FGF2: $p=0.007$; vs. control: $p<0.001$ ) (Figure 8A,B). Dovitinib did not regulate TGFB1 gene expression, there was a strong trend towards downregulation of $S E M A 3 A$ (Dovitinib vs. control: $p=0.062$ ) (Figure 8A,B). 

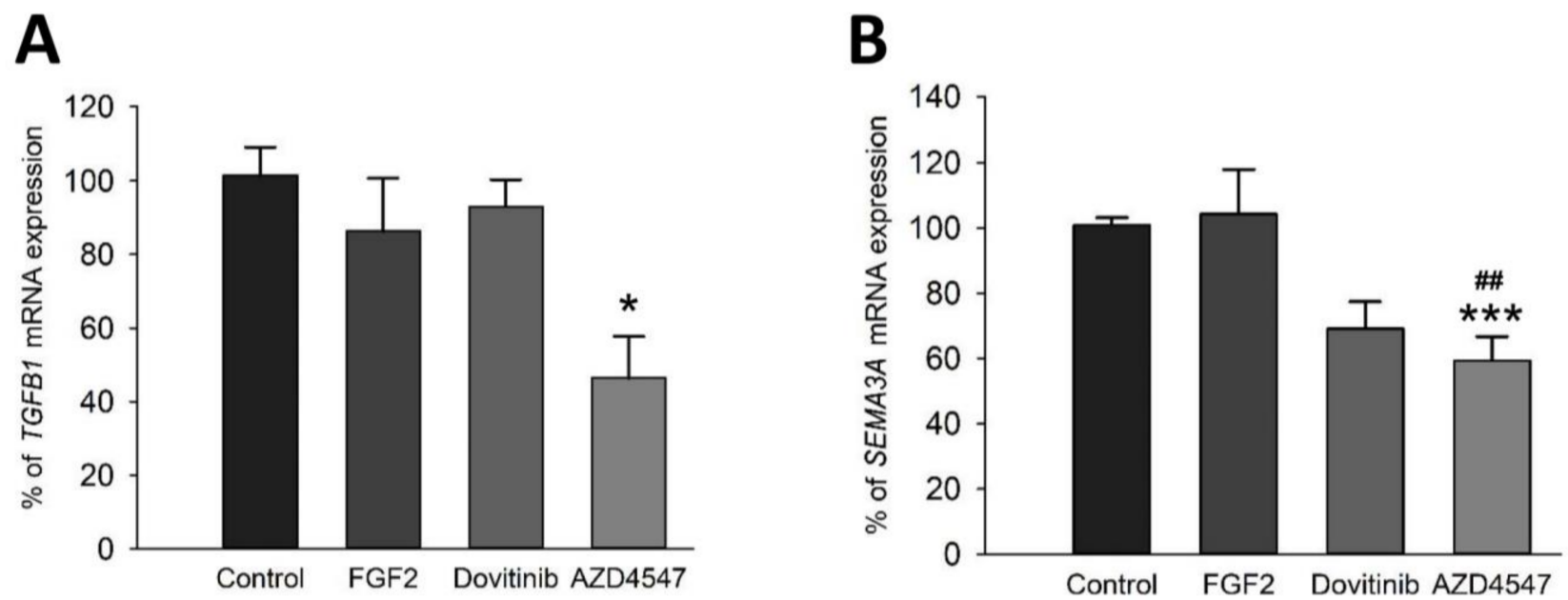

Figure 8. mRNA levels of TGF $\beta 1$ and SEMA3A. Expression of TGF $\beta$ (A) and SEMA3A (B) mRNA was reduced by AZD4547. While dovitinib and FGF2 did not regulate TGF $\beta$ (TGFB1) mRNA (A), AZD4547 reduced TGF $\beta$ mRNA expression (A) as well as mRNA levels of SEMA3A $(S E M A 3 A)\left(\right.$ B). Data are presented as mean \pm SEM. ${ }^{*} p<0.05,{ }^{* * *} p<0.001$ vs. control; \#\# $p<0.005$ vs. FGF2.

\section{Discussion}

There is increasing evidence for a role of FGF/FGFR signaling in the pathogenesis of MS and its disease model EAE. We recently showed that OL-specific deletion of either FGFR1 or FGFR2 resulted in a less severe disease course in $\mathrm{MOG}_{35-55}$-induced EAE [16,17]. Furthermore, detrimental effects of FGFR signaling in OLs on inflammation, myelin and axons were found in this disease model, highlighting the importance for the investigation of FGFR signaling in these myelin-producing cells. Therefore, to extend our understanding of FGFR signaling in oligodendrocytes, we studied the effects of pharmacological inhibition of FGFR in OLN-93 cells using the tyrosine kinase inhibitors dovitinib and AZD4547. We propose that the characterization of effects caused by FGFR inhibition in OLs can be a step towards the development of therapeutics abrogating impaired remyelination in MS.

To date, research on the function of FGFRs in oligodendrocytes has been done in knockout mice. The studies revealed that activation of ERK and Akt is central to the function of OPCs and OLs. These signaling proteins take part in pathways involved in proliferation and differentiation programs including process outgrowth and myelination [33-37]. Thus, ERK and Akt are considered to be important cellular actors in the OL cell cycle $[38,39]$ and presumably the most important signaling molecules downstream of FGFRs [40]. Furthermore, FGFR inhibitors applied to FGFR ${ }^{+}$cancer cells reduce the downstream signal transducers pERK and pAkt $[19,41-43]$. However, inhibition of the FGFR pathway specifically in OLs has not been explicitly studied yet. In the present in vitro experiments, both inhibitors of FGFRs reduced the proliferation of OLN-93 cells. Accordingly, FGFR inhibitors exert anti-proliferative effects in tumor cells [44,45] and vice versa, FGFs increase proliferation in various cells including OPCs [46-49]. This anti-proliferative effect of FGFR inhibition in OLN-93 cells was accompanied by a significant reduction of pErk and pAkt expression. There is considerable evidence that ERK and Akt are promoters of myelination [33-35,39]. Crosstalk between these two through mTOR signaling [34,36], as well as activation and inhibition of other pathways are probably involved in myelination and differentiation of OLs. In EAE, OL-specific deletion of FGFR1 and FGFR2 resulted in an upregulation of pAkt in the chronic phase of EAE. Since ERK/Akt levels were not changed in the acute phase of EAE, at a time point when beneficial effects of FGFR deletion were already present, activation of other pathways may account for the effects on myelin $[16,17]$. In this in vitro study, inhibition of FGFRs in OLs resulted in reduced phosphorylation of both direct downstream targets ERK and Akt. Despite the reduction of key signal proteins, 
an increase in myelin expression was observed, suggesting that in OLN-93 cells alternative supplementary or separate promyelinating pathways exist.

An alternative pathway modulating myelination may involve BDNF/TrkB signaling. In EAE, deletion of FGFR1 in OL resulted in an upregulation of BDNF/TrkB and less myelin loss [16]. BDNF increases inflammation in the CNS, while acting as a protective factor for axons in EAE [50]. Its deletion accordingly leads to more severe clinical activity, reduced axonal density and increased demyelination in the acute phase of EAE [51]. Thus, a neuroprotective effect of BDNF/TrkB signaling in an immune-dependent demyelinated setting, such as in EAE, supports the concept of neuroprotective autoimmunity [52]. Furthermore, administration of a TrkB agonist resulted in neuroprotective effects in EAE, including decreased OL loss and inflammation, less demyelination and increased remyelination [53]. A promyelinating effect of BDNF/TrkB signaling also seemed to be present in an oligodendrocyte monoculture setting without immune cells. Findings from our in vitro experiments show that FGFR inhibition in OLN-93 cells inhibits canonical downstream signal transducers, while simultaneously activating the BDNF/TrkB pathway, that was previously considered to be independent. Taken together, reduced ERK/Akt expression associated with increased BDNF/TrkB levels suggest that OLs are capable of compensatory responses following FGFR inhibition.

In agreement with our hypothesis, inhibition of FGFR resulted in increased expression of myelin-specific proteins. Promotion of cell cycle switches in mature OLs with potential for myelination may take place. Even though FGFs are required for developmental myelination and may enhance proliferation of OPCs [49,54], their effects vary dependent on the microenvironment, presence of other cells, and the differentiation state of OLs. Concordantly with our results from cell-specific FGFR knockout studies in EAE [16,17], in vitro data support the view that inhibition of FGFR signaling in OLs results in enhanced myelination. Furthermore, the inhibitor of remyelination SEMA3A was reduced in OLspecific FGFR1 and FGFR2 knockout mice in EAE [16,17]. SEMA3A has not only been suggested to inhibit remyelination, it may also modulate immune responses by balancing T cell inflammation [32]. TGF $\beta$, which has several cell-specific immunomodulatory roles, exerts anti-inflammatory effects on the microglia in the CNS $[55,56]$. Taken together, FGFR inhibition in OLN-93 cells does not only result in an increase of myelin proteins, it also decreases the expression of myelin inhibitors. Thus, inhibition of FGFR signaling in OLs induces myelination and intrinsically decreases inhibition of myelination.

The effects of the two inhibitors used in this study are similar but with different mechanisms. AZD4547 altered cell responses on the genetic level. It distinctly lowered the amount of FGFR1 mRNA, increased BDNF and TrkB mRNA and, more subtly, the CNP mRNA level in comparison to dovitinib. AZD4547 reduced myelin inhibitors TGF $\beta$ and SEMA3A. Surprisingly, alteration of expression patterns did not always result in higher protein expression. Here, dovitinib treatment resulted in distinct effects on downstream signaling (pERK, pAkt) compensatory pro-myelinating signals (BDNF, TrkB) and a slightly higher effect on myelin proteins. However, none of the differences between the two substances were statistically significant-except for a difference in mRNA levels of TrkB. The trend towards stronger action by dovitinib may point towards the relevance of other tyrosine kinases inhibited by dovitinib. These include VEGFRs, c-kit, colony stimulating factor 1 receptor (CSF1R), FMS-like tyrosine kinase 3 (FLT3) and PDGFRs [57]. CSFR1 is also inhibited by AZD4547 at a similar $\mathrm{IC}_{50}$ and will thus not explain the differences. All of the above-mentioned receptors are presumably expressed by oligodendrocytes at least either after injury or in progenitor states [58-62]. It is conceivable, that the effects of dovitinib are enhanced by its lower selectivity. Especially PDGFRs in mature OLs may be important for the enhanced response in the presence of dovitinib, as this receptor acts analogously to FGFRs $[63,64]$.

The in vitro results from this study may be difficult to transfer to the CNS, where various cell types interact. However, EAE studies demonstrate that FGF/FGFR signaling affects myelination. Furthermore, most of the data from MS and demyelinating models 
show that FGFs accumulate in demyelinated lesions $[13,14,65,66]$. In EAE, effects of FGFR signaling are different between disease phases, but FGFR signaling is detrimental in the pathogenesis of EAE [16,17]. FGF2 and FGF9 were downregulated in the chronic phase of EAE in OL-specific FGFR2 knockout mice [17]. MS research has focused on ligands rather than receptors. FGF2 levels in the CSF are elevated in patients [15] and FGF2 ${ }^{+}$ microglia are present in active MS lesions [13]. FGF9 is increased primarily in OLs in active as well as in the boundary zone of chronic active lesions suggesting that it blocks myelination [14]. In contrast, it has been proposed that FGFs act as recruiting factors for OPCs thus promoting remyelination. Taken together, FGFs may initially be conducive to recruitment and proliferation, but their continued presence may inhibit remyelination.

Both AZD4547 and dovitinib led to a significant decrease of FGFR1 ${ }^{+}$cells upon inhibition of the receptor. Other than expected, OLN-93 cells showed no response to FGFR1 inhibition as explained by a proposed negative feedback loop that upregulates FGFR1 expression. Further, FGFR1 could be either post-transcriptionally degraded (dovitinib) or its mRNA expression decreased (AZD4547), suggesting a double negative feedback loop. In fact, this scenario has been described earlier, in which FGFR1 mRNA levels in OPCs decline after exposure to FGF2 [67]. However, our results showed a reverse effect to the absence of FGFR1-dependent signaling. This may underline the relevance of high abundance of FGF2 in a disease state such as EAE and MS, where FGF2 will continuously activate the signaling pathway which is otherwise down-regulated by auto-negative feedback. In this scenario, continuously increased levels of FGF2 from various sources activate the cellular pathway that is otherwise heavily confined by self-regulatory mechanisms, thus leading to detrimental effects for remyelination.

In summary, we showed that pharmacological inhibition of FGFRs successfully disrupted the FGFR signaling cascade with alterations in intrinsic cellular responses and myelin production. It is conceivable that decreased phosphorylation of ERK and Akt induces an upregulation of BDNF/TrkB signaling leading to enhanced production of myelin-specific proteins. Considering that inhibition of FGFRs is currently being used in various cancer trials, these tyrosine kinase inhibitors should be administrated in preclinical studies to evaluate their potential for remyelination and, if successful, applied in MS research trials.

Supplementary Materials: The following are available online at https:/ / www.mdpi.com/article/10 .3390 / cells10061318/s1, Table S1. List of antibodies used in this study, Table S2. List of primers used in this study.

Author Contributions: M.B. and R.R. designed the study and provided conceptualization. R.R. and B.S. are responsible for methodology. N.D. and R.R. performed the experiments, validation, and quantification of the data. R.R. and M.B. analyzed the data. C.S., S.E., S.K., G.B., R.R., V.R. and M.B. provided investigative and intellectual contribution and participated in discussion. G.B. wrote the original draft. M.B., S.K., C.S., V.R. and R.R. reviewed and edited the manuscript. M.B. supervised the experiments and administrated the project. All authors have read and agreed to the published version of the manuscript.

Funding: This research received no external funding.

Institutional Review Board Statement: Not applicable.

Informed Consent Statement: Not applicable.

Data Availability Statement: The data presented in this study are available on request from the corresponding author.

Acknowledgments: G.B. was supported by Gemeinnützige Hertie-Stiftung (P1200033), N.D. by the Justus-Liebig University Trainee program.

Conflicts of Interest: The authors declare no conflict of interest. 


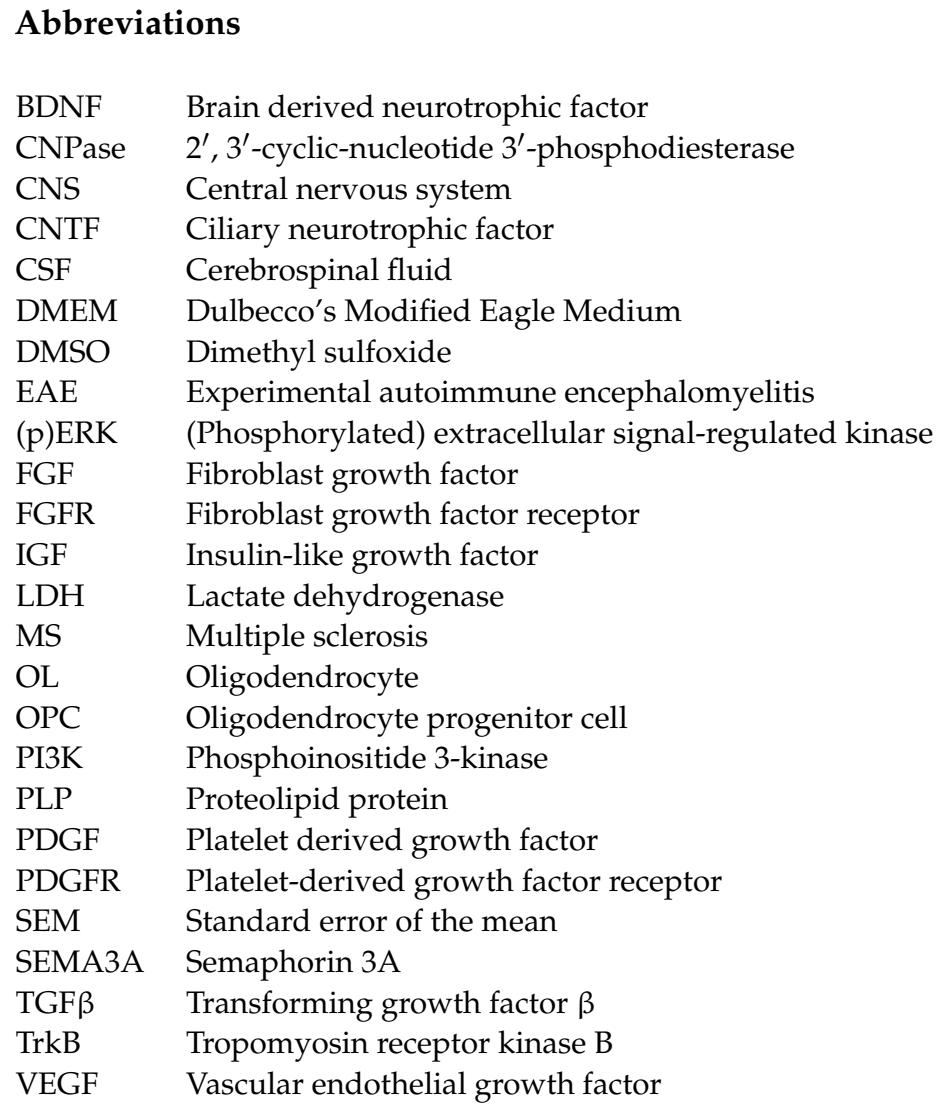

\section{References}

1. Franklin, R.J.M.; Ffrench-Constant, C. Regenerating CNS myelin-from mechanisms to experimental medicines. Nat. Rev. Neurosci. 2017, 18, 753-769. [CrossRef] [PubMed]

2. Thompson, A.J.; Baranzini, S.E.; Geurts, J.; Hemmer, B.; Ciccarelli, O. Multiple sclerosis. Lancet 2018, 391, 1622-1636. [CrossRef]

3. Nave, K.-A.; Werner, H.B. Myelination of the Nervous System: Mechanisms and Functions. Annu. Rev. Cell Dev. Biol. 2014, 30, 503-533. [CrossRef] [PubMed]

4. Stadelmann, C.; Timmler, S.; Barrantes-Freer, A.; Simons, M. Myelin in the Central Nervous System: Structure, Function, and Pathology. Physiol. Rev. 2019, 99, 1381-1431. [CrossRef] [PubMed]

5. Franklin, R.J.; Kotter, M.R. The biology of CNS remyelination: The key to therapeutic advances. J. Neurol. 2008, 255, 19-25. [CrossRef] [PubMed]

6. Goldschmidt, T.; Antel, J.; Konig, F.B.; Bruck, W.; Kuhlmann, T. Remyelination capacity of the MS brain decreases with disease chronicity. Neurology 2009, 72, 1914-1921. [CrossRef]

7. Boyd, A.; Zhang, H.; Williams, A. Insufficient OPC migration into demyelinated lesions is a cause of poor remyelination in MS and mouse models. Acta Neuropathol. 2013, 125, 841-859. [CrossRef]

8. Kuhlmann, T.; Miron, V.; Cuo, Q.; Wegner, C.; Antel, J.; Bruck, W. Differentiation block of oligodendroglial progenitor cells as a cause for remyelination failure in chronic multiple sclerosis. Brain 2008, 131, 1749-1758. [CrossRef]

9. Crawford, A.H.; Chambers, C.; Franklin, R.J.M. Remyelination: The True Regeneration of the Central Nervous System. J. Comp. Pathol. 2013, 149, 242-254. [CrossRef]

10. Acosta, C.M.; Cortes, C.; MacPhee, H.; Namaka, M.P. Exploring the role of nerve growth factor in multiple sclerosis: Implications in myelin repair. CNS Neurol. Disord. Drug Targets 2013, 12, 1242-1256. [CrossRef]

11. Huang, Y.; Dreyfus, C.F. The role of growth factors as a therapeutic approach to demyelinating disease. Exp. Neurol. 2016, 283, 531-540. [CrossRef]

12. Mohan, H.; Friese, A.; Albrecht, S.; Krumbholz, M.; Elliott, C.L.; Arthur, A.; Menon, R.; Farina, C.; Junker, A.; Stadelmann, C.; et al. Transcript profiling of different types of multiple sclerosis lesions yields FGF1 as a promoter of remyelination. Acta Neuropathol. Commun. 2014, 2. [CrossRef]

13. Clemente, D.; Ortega, M.C.; Arenzana, F.J.; De Castro, F. FGF-2 and Anosmin-1 Are Selectively Expressed in Different Types of Multiple Sclerosis Lesions. J. Neurosci. 2011, 31, 14899-14909. [CrossRef]

14. Lindner, M.; Thümmler, K.; Arthur, A.; Brunner, S.; Elliott, C.; McElroy, D.; Mohan, H.; Williams, A.; Edgar, J.M.; Schuh, C.; et al. Fibroblast growth factor signalling in multiple sclerosis: Inhibition of myelination and induction of pro-inflammatory environment by FGF9. Brain 2015, 138, 1875-1893. [CrossRef] [PubMed] 
15. Sarchielli, P.; Di Filippo, M.; Ercolani, M.V.; Chiasserini, D.; Mattioni, A.; Bonucci, M.; Tenaglia, S.; Eusebi, P.; Calabresi, P. Fibroblast growth factor-2 levels are elevated in the cerebrospinal fluid of multiple sclerosis patients. Neurosci. Lett. 2008, 435, 223-228. [CrossRef]

16. Rajendran, R.; Giraldo-Velasquez, M.; Stadelmann, C.; Berghoff, M. Oligodendroglial fibroblast growth factor receptor 1 gene targeting protects mice from experimental autoimmune encephalomyelitis through ERK/AKT phosphorylation. Brain Pathol. 2018, 28, 212-224. [CrossRef]

17. Kamali, S.; Rajendran, R.; Stadelmann, C.; Karnati, S.; Rajendran, V.; Giraldo-Velasquez, M.; Berghoff, M. Oligodendrocyte-specific deletion of FGFR2 ameliorates MOG(35-55) -induced EAE through ERK and Akt signalling. Brain Pathol. 2021, 31, $297-311$. [CrossRef]

18. Gavine, P.R.; Mooney, L.; Kilgour, E.; Thomas, A.P.; Al-Kadhimi, K.; Beck, S.; Rooney, C.; Coleman, T.; Baker, D.; Mellor, M.J.; et al. AZD4547: An orally bioavailable, potent, and selective inhibitor of the fibroblast growth factor receptor tyrosine kinase family. Cancer Res. 2012, 72, 2045-2056. [CrossRef]

19. Delpuech, O.; Rooney, C.; Mooney, L.; Baker, D.; Shaw, R.; Dymond, M.; Wang, D.; Zhang, P.; Cross, S.; Veldman-Jones, M.; et al. Identification of Pharmacodynamic Transcript Biomarkers in Response to FGFR Inhibition by AZD4547. Mol. Cancer Ther. 2016, 15, 2802-2813. [CrossRef]

20. Aggarwal, C.; Redman, M.W.; Lara, P.N.; Borghaei, H.; Hoffman, P.; Bradley, J.D.; Newman, A.J.; Feldman, M.J.; Minichiello, K.; Miao, J.; et al. SWOG S1400D (NCT02965378), a Phase II Study of the Fibroblast Growth Factor Receptor Inhibitor AZD4547 in Previously Treated Patients With Fibroblast Growth Factor Pathway-Activated Stage IV Squamous Cell Lung Cancer (Lung-MAP Substudy). J. Thorac. Oncol. 2019, 14, 1847-1852. [CrossRef]

21. Bang, Y.-J.; Van Cutsem, E.; Mansoor, W.; Petty, R.D.; Chao, Y.; Cunningham, D.; Ferry, D.; Landers, D.; Stockman, P.; Smith, N.R.; et al. A randomized, open-label phase II study of AZD4547 (AZD) versus Paclitaxel (P) in previously treated patients with advanced gastric cancer (AGC) with Fibroblast Growth Factor Receptor 2 (FGFR2) polysomy or gene amplification (amp): SHINE study. J. Clin. Oncol. 2015, 33, 4014. [CrossRef]

22. Kim, K.B.; Chesney, J.; Robinson, D.; Gardner, H.; Shi, M.M.; Kirkwood, J.M. Phase I/II and Pharmacodynamic Study of Dovitinib (TKI258), an Inhibitor of Fibroblast Growth Factor Receptors and VEGF Receptors, in Patients with Advanced Melanoma. Clin. Cancer Res. 2011, 17, 7451-7461. [CrossRef] [PubMed]

23. Porta, R.; Borea, R.; Coelho, A.; Khan, S.; Araújo, A.; Reclusa, P.; Franchina, T.; Van Der Steen, N.; Van Dam, P.; Ferri, J.; et al. FGFR a promising druggable target in cancer: Molecular biology and new drugs. Crit. Rev. Oncol. Hematol. 2017, 113, 256-267. [CrossRef] [PubMed]

24. Katoh, M. Fibroblast growth factor receptors as treatment targets in clinical oncology. Nat. Rev. Clin. Oncol. 2019, 16, 105-122. [CrossRef]

25. Facchinetti, F.; Hollebecque, A.; Bahleda, R.; Loriot, Y.; Olaussen, K.A.; Massard, C.; Friboulet, L. Facts and New Hopes on Selective FGFR Inhibitors in Solid Tumors. Clin. Cancer Res. 2020, 26, 764-774. [CrossRef]

26. André, F.; Bachelot, T.; Campone, M.; Dalenc, F.; Perez-Garcia, J.M.; Hurvitz, S.A.; Turner, N.; Rugo, H.; Smith, J.W.; Deudon, S.; et al. Targeting FGFR with dovitinib (TKI258): Preclinical and clinical data in breast cancer. Clin. Cancer Res. 2013, 19, 3693-3702. [CrossRef]

27. Strober, W. Trypan Blue Exclusion Test of Cell Viability. Curr. Protoc. Immunol. 2015, 111. [CrossRef]

28. Livak, K.J.; Schmittgen, T.D. Analysis of Relative Gene Expression Data Using Real-Time Quantitative PCR and the $2^{-\Delta \Delta C T}$ Method. Methods 2001, 25, 402-408. [CrossRef]

29. Xiao, J.; Wong, A.W.; Willingham, M.M.; Van Den Buuse, M.; Kilpatrick, T.J.; Murray, S.S. Brain-Derived Neurotrophic Factor Promotes Central Nervous System Myelination via a Direct Effect upon Oligodendrocytes. Neurosignals 2010, 18, 186-202. [CrossRef]

30. Fletcher, J.L.; Wood, R.J.; Nguyen, J.; Norman, E.M.L.; Jun, C.M.K.; Prawdiuk, A.R.; Biemond, M.; Nguyen, H.T.H.; Northfield, S.E.; Hughes, R.A.; et al. Targeting TrkB with a Brain-Derived Neurotrophic Factor Mimetic Promotes Myelin Repair in the Brain. J. Neurosci. 2018, 38, 7088-7099. [CrossRef]

31. Han, H.; Myllykoski, M.; Ruskamo, S.; Wang, C.; Kursula, P. Myelin-specific proteins: A structurally diverse group of membraneinteracting molecules. BioFactors 2013, 39, 233-241. [CrossRef]

32. Eixarch, H.; Gutiérrez-Franco, A.; Montalban, X.; Espejo, C. Semaphorins 3A and 7A: Potential immune and neuroregenerative targets in multiple sclerosis. Trends Mol. Med. 2013, 19, 157-164. [CrossRef]

33. Flores, A.I.; Narayanan, S.P.; Morse, E.N.; Shick, H.E.; Yin, X.H.; Kidd, G.; Avila, R.L.; Kirschner, D.A.; Macklin, W.B. Constitutively active Akt induces enhanced myelination in the CNS. J. Neurosci. 2008, 28, 7174-7183. [CrossRef]

34. Narayanan, S.P.; Flores, A.I.; Wang, F.; Macklin, W.B. Akt Signals through the Mammalian Target of Rapamycin Pathway to Regulate CNS Myelination. J. Neurosci. 2009, 29, 6860-6870. [CrossRef]

35. Ishii, A.; Fyffe-Maricich, S.L.; Furusho, M.; Miller, R.H.; Bansal, R. ERK1/ERK2 MAPK Signaling is Required to Increase Myelin Thickness Independent of Oligodendrocyte Differentiation and Initiation of Myelination. J. Neurosci. 2012, 32, 8855-8864. [CrossRef]

36. Furusho, M.; Ishii, A.; Bansal, R. Signaling by FGF Receptor 2, Not FGF Receptor 1, Regulates Myelin Thickness through Activation of ERK1/2-MAPK, Which Promotes mTORC1 Activity in an Akt-Independent Manner. J. Neurosci. 2017, 37, $2931-2946$. [CrossRef] 
37. Tsiperson, V.; Gruber, R.C.; Goldberg, M.F.; Jordan, A.; Weinger, J.G.; Macian, F.; Shafit-Zagardo, B. Suppression of Inflammatory Responses during Myelin Oligodendrocyte Glycoprotein-Induced Experimental Autoimmune Encephalomyelitis Is Regulated by AKT3 Signaling. J. Immunol. 2013, 190, 1528-1539. [CrossRef]

38. Furusho, M.; Dupree, J.L.; Nave, K.A.; Bansal, R. Fibroblast Growth Factor Receptor Signaling in Oligodendrocytes Regulates Myelin Sheath Thickness. J. Neurosci. 2012, 32, 6631-6641. [CrossRef]

39. Ishii, A.; Furusho, M.; Dupree, J.L.; Bansal, R. Role of ERK1/2 MAPK Signaling in the Maintenance of Myelin and Axonal Integrity in the Adult CNS. J. Neurosci. 2014, 34, 16031-16045. [CrossRef]

40. Ornitz, D.M.; Itoh, N. The Fibroblast Growth Factor signaling pathway. Wiley Interdiscip. Rev. Dev. Biol. 2015, 4, 215-266. [CrossRef]

41. Das, A.; Martinez Santos, J.L.; Alshareef, M.; Porto, G.B.F.; Infinger, L.K.; Vandergrift, W.A., 3rd; Lindhorst, S.M.; Varma, A.K.; Patel, S.J.; Cachia, D. In Vitro Effect of Dovitinib (TKI258), a Multi-Target Angiokinase Inhibitor on Aggressive Meningioma Cells. Cancer Investig. 2020, 38, 349-355. [CrossRef] [PubMed]

42. Huynh, H.; Chow, P.K.H.; Tai, W.M.; Choo, S.P.; Chung, A.Y.F.; Ong, H.S.; Soo, K.C.; Ong, R.; Linnartz, R.; Shi, M.M. Dovitinib demonstrates antitumor and antimetastatic activities in xenograft models of hepatocellular carcinoma. J. Hepatol. 2012, 56, 595-601. [CrossRef]

43. Zhang, H.; Hylander, B.L.; Levea, C.; Repasky, E.A.; Straubinger, R.M.; Adjei, A.A.; Ma, W.W. Enhanced FGFR signalling predisposes pancreatic cancer to the effect of a potent FGFR inhibitor in preclinical models. Br. J. Cancer 2014, 110, 320-329. [CrossRef] [PubMed]

44. Holzhauser, S.; Lukoseviciute, M.; Andonova, T.; Ursu, R.G.; Dalianis, T.; Wickström, M.; Kostopoulou, O.N. Targeting Fibroblast Growth Factor Receptor (FGFR) and Phosphoinositide 3-kinase (PI3K) Signaling Pathways in Medulloblastoma Cell Lines. Anticancer Res. 2020, 40, 53-66. [CrossRef] [PubMed]

45. Katoh, M.; Nakagama, H. FGF Receptors: Cancer Biology and Therapeutics. Med. Res. Rev. 2014, 34, 280-300. [CrossRef] [PubMed]

46. Gospodarowicz, D.; Neufeld, G.; Schweigerer, L. Molecular and biological characterization of fibroblast growth factor, an angiogenic factor which also controls the proliferation and differentiation of mesoderm and neuroectoderm derived cells. Cell Differ. 1986, 19, 1-17. [CrossRef]

47. Wesche, J.; Haglund, K.; Haugsten, E.M. Fibroblast growth factors and their receptors in cancer. Biochem. J. 2011, 437, 199-213. [CrossRef]

48. Baron, W.; Metz, B.; Bansal, R.; Hoekstra, D.; de Vries, H. PDGF and FGF-2 signaling in oligodendrocyte progenitor cells: Regulation of proliferation and differentiation by multiple intracellular signaling pathways. Mol. Cell. Neurosci. 2000, 15, 314-329. [CrossRef]

49. Fortin, D. Distinct Fibroblast Growth Factor (FGF)/FGF Receptor Signaling Pairs Initiate Diverse Cellular Responses in the Oligodendrocyte Lineage. J. Neurosci. 2005, 25, 7470-7479. [CrossRef]

50. Linker, R.A.; Lee, D.H.; Demir, S.; Wiese, S.; Kruse, N.; Siglienti, I.; Gerhardt, E.; Neumann, H.; Sendtner, M.; Luhder, F.; et al. Functional role of brain-derived neurotrophic factor in neuroprotective autoimmunity: Therapeutic implications in a model of multiple sclerosis. Brain 2010, 133, 2248-2263. [CrossRef]

51. Lee, D.H.; Geyer, E.; Flach, A.C.; Jung, K.; Gold, R.; Flügel, A.; Linker, R.A.; Lühder, F. Central nervous system rather than immune cell-derived BDNF mediates axonal protective effects early in autoimmune demyelination. Acta Neuropathol. 2012, 123, 247-258. [CrossRef] [PubMed]

52. Stadelmann, C.; Kerschensteiner, M.; Misgeld, T.; Brück, W.; Hohlfeld, R.; Lassmann, H. BDNF and gp145trkB in multiple sclerosis brain lesions: Neuroprotective interactions between immune and neuronal cells? Brain 2002, 125, 75-85. [CrossRef] [PubMed]

53. Makar, T.K.; Nimmagadda, V.K.; Singh, I.S.; Lam, K.; Mubariz, F.; Judge, S.I.; Trisler, D.; Bever, C.T., Jr. TrkB agonist, 7,8dihydroxyflavone, reduces the clinical and pathological severity of a murine model of multiple sclerosis. J. Neuroimmunol. 2016, 292, 9-20. [CrossRef] [PubMed]

54. Guillemot, F.; Zimmer, C. From cradle to grave: The multiple roles of fibroblast growth factors in neural development. Neuron 2011, 71, 574-588. [CrossRef]

55. Goldmann, T.; Wieghofer, P.; Müller, P.F.; Wolf, Y.; Varol, D.; Yona, S.; Brendecke, S.M.; Kierdorf, K.; Staszewski, O.; Datta, M.; et al. A new type of microglia gene targeting shows TAK1 to be pivotal in CNS autoimmune inflammation. Nat. Neurosci. 2013, 16, 1618-1626. [CrossRef]

56. Zöller, T.; Schneider, A.; Kleimeyer, C.; Masuda, T.; Potru, P.S.; Pfeifer, D.; Blank, T.; Prinz, M.; Spittau, B. Silencing of TGF $\beta$ signalling in microglia results in impaired homeostasis. Nat. Commun. 2018, 9, 4011. [CrossRef]

57. Katoh, M. FGFR inhibitors: Effects on cancer cells, tumor microenvironment and whole-body homeostasis (Review). Int. J. Mol. Med. 2016, 38, 3-15. [CrossRef]

58. Kuçi, S.; Kuçi, Z.; Schmid, S.; Seitz, G.; Müller, I.; Dufke, A.; Leimig, T.; Murti, G.; Jurecic, R.; Schumm, M.; et al. Efficient in vitro generation of adult multipotent cells from mobilized peripheral blood CD133+ cells. Cell Prolif. 2008, 41, 12-27. [CrossRef]

59. Yamasaki, K.; Setoguchi, T.; Takenouchi, T.; Yone, K.; Komiya, S. Stem cell factor prevents neuronal cell apoptosis after acute spinal cord injury. Spine 2009, 34, 323-327. [CrossRef] 
60. Sentilhes, L.; Marret, S.; Leroux, P.; Gonzalez, B.J.; Laquerrière, A. Vascular-endothelial growth factor and its high affinity receptor VEGFR-2 in the normal versus destructive lesions human forebrain during development: An immuno-histochemical comparative study. Brain Res. 2011, 1385, 77-86. [CrossRef]

61. Funa, K.; Sasahara, M. The roles of PDGF in development and during neurogenesis in the normal and diseased nervous system. J. Neuroimmune Pharmacol. 2014, 9, 168-181. [CrossRef]

62. Zhu, Q.; Zhao, X.; Zheng, K.; Li, H.; Huang, H.; Zhang, Z.; Mastracci, T.; Wegner, M.; Chen, Y.; Sussel, L.; et al. Genetic evidence that Nkx2.2 and Pdgfra are major determinants of the timing of oligodendrocyte differentiation in the developing CNS. Development 2014, 141, 548-555. [CrossRef]

63. Zhou, L.; Shao, C.Y.; Xie, Y.J.; Wang, N.; Xu, S.M.; Luo, B.Y.; Wu, Z.Y.; Ke, Y.H.; Qiu, M.; Shen, Y. Gab1 mediates PDGF signaling and is essential to oligodendrocyte differentiation and CNS myelination. eLife 2020, 9. [CrossRef]

64. Shen, J.; Ishii, Y.; Xu, G.; Dang, T.C.; Hamashima, T.; Matsushima, T.; Yamamoto, S.; Hattori, Y.; Takatsuru, Y.; Nabekura, J.; et al. PDGFR- $\beta$ as a positive regulator of tissue repair in a mouse model of focal cerebral ischemia. J. Cereb. Blood Flow Metab. 2012, 32, 353-367. [CrossRef]

65. Armstrong, R.C.; Le, T.Q.; Flint, N.C.; Vana, A.C.; Zhou, Y.-X. Endogenous Cell Repair of Chronic Demyelination. J. Neuropathol. Exp. Neurol. 2006, 65, 245-256. [CrossRef]

66. Messersmith, D.J.; Murtie, J.C.; Le, T.Q.; Frost, E.E.; Armstrong, R.C. Fibroblast growth factor 2 (FGF2) and FGF receptor expression in an experimental demyelinating disease with extensive remyelination. J. Neurosci. Res. 2000, 62, 241-256. [CrossRef]

67. Bansal, R.; Kumar, M.; Murray, K.; Morrison, R.S.; Pfeiffer, S.E. Regulation of FGF receptors in the oligodendrocyte lineage. Mol. Cell. Neurosci. 1996, 7, 263-275. [CrossRef] 